Methods: In total, ninety-four patients with PsA, who fulfilled the disease criteria (CASPAR) were examined using standard diagnostic methods (including C-reactive protein, lipid profile). The QRISK-3 and SCORE scales were used to assess the 10-year risk of CVD.

Results: Intermediate $(12.4 \pm 0,75 \%)$ risk of adverse cardiovascular events within the next 10 years was estimated for PsA patients and it was 7 to 8 fold higher than the $\mathrm{Q}$ - score of a healthy age, sex, and ethnicity - matched subjects. Using classical SCORE, the risk was estimated as low $(1,9 \pm 0.24$ $\%)$. Healthy Heart Age was about $25 \%$ higher than predicted as assessed by QRISK.

Conclusion: The Q-risk Scale considers not only classical of such risk factors as age, sex, smoking, systolic blood pressure, total cholesterol (which used SCORE) but also index of atherogenity, BMI, family history of coronary artery disease, treatment with antihypertensive drugs and glucocorticosteroids, comorbidity, systemic inflammatory disease and can be used for different age groups and ethnicity.

Q-risk scale appears to be adaptive and informative in patients with chronic inflammatory and autoimmune diseases as compared with SCORE, because it uses mostly all important etiological and trigger factors of CVD especially presence autoimmune inflammatory process in our case.

REFERENCES:

[1] Abrar Ahmed Wagan. Cardiovascular risk score in Rheumatoid Arthritis. Pak J Med Sci, Vol. 32, Issue 3, 2016, P.534-538

[2] Frank Verhoeven, Clément Prati. Cardiovascular risk in psoriatic arthritis, a narrative review. Joint Bone Spine, Vol. 87, Issue 5, 2020, P.413-418;

[3] Julia Hippisley-Cox, Carol Coupland. Development and validation of QRISK3 risk prediction algorithms to estimate future risk of cardiovascular disease: prospective cohort study. BMJ, Vol. 23, 2017, P.357;

[4] Naveen Garg, Subrat K. Muduli. Comparison of different cardiovascular risk score calculators for cardiovascular risk prediction and guideline recommended statin uses. Indian Heart J, Vol. 69, Issue 4, 2017, P.458-463;

Disclosure of Interests: None declared.

DOI: 10.1136/annrheumdis-2021-eular.905

\section{AB0568 CORRELATION BETWEEN SKIN AND JOINT INVOLVEMENT IN PATIENTS WITH PSORIATIC ARTHRITIS: EXPERIENCE FROM A THIRD LEVEL HOSPITAL}

C. Sieiro Santos ${ }^{1}$, C. Moriano ${ }^{1}$, C. Álvarez Castro ${ }^{1}$, X. E. Larco Rojas ${ }^{1}$, E. Diez Alvarez ${ }^{1}$, T. Pérez Sandoval ${ }^{1} .{ }^{1}$ Complejo Asistencial Universitario de León, Rheumatology, León, Spain

Background: Determining the relationship between severity of skin and joint disease is essential for better phenotyping of patients and determine whether clinical features of arthritis can associate with psoriasis.

Objectives: To characterize the relationship between skin and joint activity in patients with psoriatic arthritis (PsA) and psoriasis (PsO) at enrolment.

Methods: We performed a retrospective and descriptive study including patients diagnosed with PsA with a history of PsO. Age, sex, disease onset and duration, pattern of PsA and $\mathrm{PsO}$, sites of skin and joint involvement were collected. PsA patients were evaluated at enrolment for skin activity by Psoriasis Area and Severity Index (PASI), joint activity by Disease Activity Score 28 (DAS28) for peripheral arthritis and Bath Ankylosing Spondylitis Disease Activity Index (BASDAI) for axial involvement. A PASI>10\% was used to define moderate-severe psoriasis (MS-P). We compared clinical characteristics of patients with PsA based on PASI score and evaluated the relationship of skin and joint activity with linear regression.

Results: A total of 50 patients were collected, $64 \%$ were women with a mean age of $57.4 \pm 11.9$ years. Patients with MS-P had a long-standing history of $\mathrm{PsO}(16.6 \pm 7.9$ vs $14.15 \pm 8.2$ years, $\mathrm{p} 0.03)$ and arthritis (12.2 \pm 7.6 vs $10.6 \pm 7.6$ years, $\mathrm{p} 0.05)$. PsO was diagnosed more frequently before arthritis in the group of MS-P (73\% vs 42\%, p 0.03). Nail (73\% vs 34\%, OR 4.27 (1.38$20.14), p$ 0.015) and hairline psoriasis ( $67 \%$ vs $29 \%$, OR 5 (1.36-18.35), p 0.03 ) were more frequent in the group of MS-P. Polyarthritis was the most common clinical pattern $(60 \%$ vs $26 \%$, p 0.02) and peripheral arthritis, in shoulder, elbows and wrists was more associated to patients with MS-P. No significant difference regarding sex, age, arthritis onset, dactylitis, enthesitis or HLA-B27 was found. Patients with MS-P had a higher joint activity for peripheral arthritis (4.1 vs 2.44 , p 0.02). The correlation between the skin and joint activity was positive and statistically significant $r=0.568$ ( $p$ 0.02), (graph 1).

Conclusion: Patients with PSA with MS-P associate nail and hairline psoriasis, polyarthritis, and peripheral joint involvement more often. Cutaneous disease activity is correlated with joint activity. Collaboration between dermatologists and rheumatologists is recommended for a proper assessment of psoriatic arthritis with skin involvement.

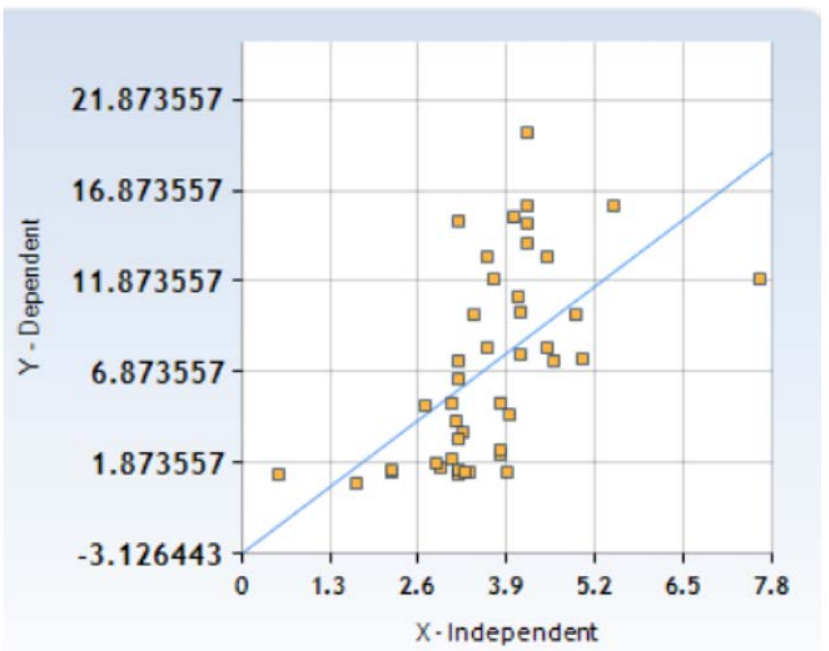

- Regression Line $(\hat{y}=2.83 X-3.13)$

Graph 1. Correlation between skin and joint activity

Table 1. Demographic and clinical characteristics of 50 patients

\begin{tabular}{|c|c|c|c|c|}
\hline & $\begin{array}{l}\text { PASI }<10 \% \\
\mathrm{~N}=35\end{array}$ & $\begin{array}{l}\mathrm{PASI}>10 \% \\
\mathrm{~N}=15\end{array}$ & OR $95 \%$ IC & $P$ value \\
\hline Age & $54.4 \pm 10.4$ & $53.9 \pm 12.9$ & - & 0.86 \\
\hline Female & $63 \%$ & $73 \%$ & $0.62(0.16-2.34)$ & 0.53 \\
\hline Duration of psoriasis & $14.15 \pm 8.2$ & $16.6 \pm 7.9$ & - & 0.03 \\
\hline Duration of arthritis & $10.6 \pm 7.4$ & $12.2 \pm 7.6$ & - & 0.05 \\
\hline Psoriasis onset & $42 \%$ & $73 \%$ & $3.67(1.97-13.8)$ & 0.03 \\
\hline Arthritis onset & $17 \%$ & $20 \%$ & $1.21(0.26-5.64)$ & 1 \\
\hline Nail psoriasis & $34 \%$ & $73 \%$ & $4.27(1.38-20.14)$ & 0.015 \\
\hline Hair line & $29 \%$ & $67 \%$ & $5(1.36-18.35)$ & 0.03 \\
\hline Enthesitis & $14 \%$ & $13 \%$ & $1.08(0.19-6.32)$ & 0.96 \\
\hline Dactylitis & $20 \%$ & $33 \%$ & $0.5(0.13-0.96)$ & 0.47 \\
\hline HLA B27 & $34 \%$ & $13 \%$ & $3.39(0.66-17.56)$ & 0.18 \\
\hline \multicolumn{5}{|l|}{ Type of arthritis } \\
\hline Axial & $26 \%$ & $13 \%$ & $0.44(0.08-2.36)$ & 0.47 \\
\hline Peripheral & $42.8 \%$ & $73 \%$ & $6.88(1.77-26.76)$ & 0.05 \\
\hline Both & $31 \%$ & $13 \%$ & $0.34(0.06-1.75)$ & 0.29 \\
\hline \multicolumn{5}{|l|}{ Joint involvement } \\
\hline Back & $14 \%$ & $20 \%$ & $0.67(0.14-3.24)$ & 0.68 \\
\hline Shoulders & $17 \%$ & $53 \%$ & $5.52(1.44-21.14)$ & 0.02 \\
\hline Elbows & $5.7 \%$ & $33 \%$ & $8.25(1.38-49.21)$ & 0.02 \\
\hline Wrists & $31 \%$ & $73 \%$ & $6(1.56-23.11)$ & 0.01 \\
\hline Fingers & $54 \%$ & $60 \%$ & $1.26(0.37-4.32)$ & 0.77 \\
\hline Knees & $29 \%$ & $47 \%$ & $2.19(0.63-7.65)$ & 0.33 \\
\hline Ankles & $40 \%$ & $60 \%$ & $2.25(0.65-7.73)$ & 0.22 \\
\hline Toes & $46 \%$ & $53 \%$ & $1.36(0.4-4.56)$ & 0.76 \\
\hline \multicolumn{5}{|l|}{ Articular pattern } \\
\hline Polyarthritis & $26 \%$ & $60 \%$ & $4.33(1.2-15.61)$ & 0.02 \\
\hline Asymmetric oligoarthritis & $29 \%$ & $27 \%$ & $0.91(0.23-3.54)$ & 1 \\
\hline DIP involvement & $14.3 \%$ & $13.3 \%$ & $0.92(0.16-5.39)$ & 1 \\
\hline Spondyloarthritis & $11.4 \%$ & $13.3 \%$ & $1.19(0.19-7.33)$ & 1 \\
\hline Arthritis mutilans & - & - & - & - \\
\hline DAS28 & $2.44 \pm 0.95$ & $4.1 \pm 1.2$ & - & 0.02 \\
\hline
\end{tabular}

\section{REFERENCES:}

[1] Mease PJ, Etzel CJ, Huster WJ. Understanding the association between skin involvement and joint activity in patients with psoriatic arthritis: experience from the Corrona Registry. RMD Open. 2019 May 24;5(1):e000867. doi: 10.1136/rmdopen-2018-000867. PMID: 31245045; PMCID: PMC6560

Disclosure of Interests: None declared.

DOI: 10.1136/annrheumdis-2021-eular.1226

\section{AB0569 PSORIATIC ARTHRITIS, ALLIED DISEASES AND MORTALITY - A POSTMORTEM CLINICOPATHOLOGIC STUDY OF 12 PATIENTS}

Á. Apáthy ${ }^{1}$, M. Bély ${ }^{2} .{ }^{1}$ St. Margaret Clinic, Department of Rheumatology, Budapest, Hungary; ${ }^{2}$ Hospital of the Order of the Brothers of Saint John of God, Department of Pathology, Budapest, Hungary 